\title{
Growth and Endothelial Function in the First 2 Years of Life
}

Citation for published version (APA):

Touwslager, R. N. H., Houben, A. J. H. M., Tan, F. E. S., Gielen, M., Zeegers, M. P., Stehouwer, C. D. A., Gerver, W. J. M., Westerterp, K. R., Wouters, L., Blanco, C. E., Zimmermann, L. J., \& Mulder, A. L. M. (2015). Growth and Endothelial Function in the First 2 Years of Life. Journal of Pediatrics, 166(3), 666671.e1. https://doi.org/10.1016/j.jpeds.2014.11.059

Document status and date:

Published: 01/03/2015

DOI:

10.1016/j.jpeds.2014.11.059

Document Version:

Publisher's PDF, also known as Version of record

Document license:

Taverne

Please check the document version of this publication:

- A submitted manuscript is the version of the article upon submission and before peer-review. There can be important differences between the submitted version and the official published version of record.

People interested in the research are advised to contact the author for the final version of the publication, or visit the DOI to the publisher's website.

- The final author version and the galley proof are versions of the publication after peer review.

- The final published version features the final layout of the paper including the volume, issue and page numbers.

Link to publication

\footnotetext{
General rights rights.

- You may freely distribute the URL identifying the publication in the public portal. please follow below link for the End User Agreement:

www.umlib.nl/taverne-license

Take down policy

If you believe that this document breaches copyright please contact us at:

repository@maastrichtuniversity.nl

providing details and we will investigate your claim.
}

Copyright and moral rights for the publications made accessible in the public portal are retained by the authors and/or other copyright owners and it is a condition of accessing publications that users recognise and abide by the legal requirements associated with these

- Users may download and print one copy of any publication from the public portal for the purpose of private study or research.

- You may not further distribute the material or use it for any profit-making activity or commercial gain

If the publication is distributed under the terms of Article $25 \mathrm{fa}$ of the Dutch Copyright Act, indicated by the "Taverne" license above, 


\title{
Growth and Endothelial Function in the First 2 Years of Life
}

\author{
Robbert N. H. Touwslager, MD, PhD ${ }^{1,2,3}$, Alfons J. H. M. Houben, $\mathrm{PhD}^{4,5}$, Frans E. S. Tan, $\mathrm{PhD}^{6,7}$, Marij Gielen, MD, $\mathrm{PhD}^{3,8}$, \\ Maurice P. Zeegers, $\mathrm{PhD}^{3,8}$, Coen D. A. Stehouwer, MD, PhD ${ }^{3,4,5}$, Willem-Jan M. Gerver, MD, $\mathrm{PhD}^{1,2}$, \\ Klaas R. Westerterp, PhD ${ }^{3,9}$, Loek Wouters, BSc ${ }^{3,9}$, Carlos E. Blanco, MD, PhD ${ }^{1,2}$, Luc J. Zimmermann, MD, PhD ${ }^{1,2}$, \\ and Antonius L. M. Mulder, MD, $\mathrm{PhD}^{1,2}$
}

Objective To test the hypothesis that the inverse association between infant growth and endothelial function at 6 months would persist to 24 months and that accelerated growth would lead to an increased percent body fat, which would, in turn, impact negatively on endothelial function.

Study design In a prospective observational study, 104 healthy term newborns underwent anthropometry and measurements of vascular vasodilation at $0,6,12$, and 24 months. We recorded maximum vasodilation in response to acetylcholine (endothelium-dependent) and nitroprusside (endothelium-independent) by use of laser-Doppler vascular perfusion monitoring of the forearm skin vasculature. Additional anthropometry at 1 and 3 months was collected from child welfare centers. The data were analyzed by multilevel linear regression.

Results Weight gain from 0-1 month was associated inversely with maximum perfusion in response to acetylcholine at the age of 2 years $(b=-8.28$ perfusion units [PU] per $\Delta z$-score, $P=.03)$. Weight gain from $0-1$ month was related positively to maximum perfusion in response to nitroprusside $(\mathrm{b}=10.12 \mathrm{PU}$ per $\Delta \mathrm{z}$-score, $P=.04)$, as was birth weight $(\mathrm{b}=8.02 \mathrm{PU}$ per $z$-score, $P=.02)$. Body fat percentage did not have a significant effect in any of the perfusion models and was not related to maximum perfusion at 2 years.

Conclusion Infant weight gain from 0-1 month is inversely related to endothelial function in healthy term infants, at least to the age of 2 years. This relationship was not explained by an increased percentage body fat. ( $J$ Pediatr 2015;166:666-71).

ardiovascular disease is one of the leading causes of morbidity and mortality worldwide. ${ }^{1}$ Low birth weight is related to mortality from cardiovascular disease, which has been termed the Barker hypothesis. ${ }^{2}$ Evidence is accumulating that accelerated infant growth also is related to later risk of cardiovascular disease. ${ }^{3-6}$ Because early infant growth is largely nutrition-driven and accelerated growth may thereby be avoided, infant growth is a potential target for primary prevention of cardiovascular disease. ${ }^{7}$ There may be a complicated trade-off, however, with the beneficial effects of accelerated early growth, such as improved neurodevelopmental outcome. ${ }^{8}$

Endothelial function is considered a precursor of atherosclerosis and has been shown to precede an adverse cardiovascular phenotype in adolescents. ${ }^{9}$ We have shown previously that infant growth is associated inversely with endothelial function during the first 6 months of life. ${ }^{10}$ Growth during the first month seemed to be of particular importance. During the first few months, growth velocities are high and, moreover, especially small-for-gestational age infants are more likely to cross percentile lines. The period of high growth velocity continues until approximately 1 year of age. We now present follow-up data from our earlier study, with additional measurements of endothelial function at the ages of 12 and 24 months.

Accelerated infant growth may lead to (central) obesity in young adulthood but also as early as childhood (6-7 years). ${ }^{6,11,12}$ In children, obesity is related to endothelial dysfunction, measured both as flow-mediated dilation and by use of laser-Doppler flowmetry. ${ }^{13-16}$

In the present study, we first hypothesized that the harmful association between infant growth and endothelial function would persist to the age of 24 months and, second, that accelerated growth would lead to an increased percentage of body fat and that this would in turn impact negatively on endothelial function.

\section{Methods}

The selection of the study population was described previously in detail. ${ }^{17}$ In short, at Maastricht University Medical Centre, Maastricht, The Netherlands,

$\begin{array}{ll}\text { FFM } & \text { Fat-free mass } \\ \text { NO } & \text { Nitric oxide } \\ \text { PU } & \text { Perfusion units } \\ \text { TBW } & \text { Total amount of water in the body }\end{array}$

From the ${ }^{1}$ Department of Pediatrics, Maastricht University Medical Centre; ${ }^{2}$ Maastricht School for Oncology and Developmental Biology (GROW); ${ }^{3}$ Nutrition and Toxicology Research Institute Maastricht (NUTRIM); ${ }^{4}$ Department of Internal Medicine, Maastricht University Medical Centre; ${ }^{5}$ Maastricht School for Cardiovascular Diseases (CARIM); ${ }^{6}$ Department of Methodology and Statistics, Maastricht University; ${ }^{7}$ School for Public Health and Primary Care (CAPHRI); and ${ }^{8}$ Section of Complex Genetics, Department of Genetics and Cell Biology, and ${ }^{9}$ Department of Human Biology, Maastricht University, Maastricht, The Netherlands

R.T. is supported by a Kootstra Fellowship from the University of Maastricht and a 'Profileringsfonds' grant from Maastricht University Medical Centre (PF 283). The authors declare no conflicts of interest.

0022-3476/\$ - see front matter. Copyright (๑) 2015 Elsevier Inc. All rights reserved.

http://dx.doi.org/10.1016/j.jpeds.2014.11.059 
we recruited healthy term newborns (gestational age 37-42 weeks) from January 2006 to May 2010. For logistical reasons, they had to remain admitted to the hospital for at least 3 days. Ethical approval was given by the Medical Ethics Committee of the Maastricht University Medical Centre. All parents provided written informed consent.

A detailed description of the vascular measurements was published previously. ${ }^{17}$ In short, we performed the measurements in the first week (0 months) and at the ages of 6,12 , and 24 months. At 0 months, measurements were taken when the newborns were asleep, mostly after feeding. At 6 months, the infants were mostly measured awake, lying in their own baby seat. At 12 and 24 months, the infants and children were measured on their parent's lap or in their stroller while they were watching a video, looking at a picture book, or while sleeping.

We gently fixed the forearm to minimize movement artifacts. We recorded microvascular skin blood flow of the dorsal side of the forearm by use of single-point laser-Doppler flowmetry (Periflux system 5000; Perimed A.B., Järfälla, Sweden) before and after pharmacologically induced vasodilatation. We fixed the temperature of the probe to $32^{\circ} \mathrm{C}$. Blood perfusion was recorded in perfusion units (PU), which correlate with the number and velocity of passing blood cells in the skin microvasculature. We induced endothelium-dependent vasodilation by iontophoresis of acetylcholine, which releases nitric oxide (NO) and prostanoids from the endothelium (with a possible accessory role for endothelium-derived hyperpolarization factor). ${ }^{18}$ Multiple successive doses were given, resulting in a cumulative dose response curve. Endotheliumindependent vasodilation was induced by iontophoresis of nitroprusside, a direct NO donor. ${ }^{19}$ One experienced researcher (R.T.) extracted the average perfusion values in a steady period of at least 30 seconds without significant movement artifacts at baseline (covariates) and at maximum attained perfusion (primary outcome variables) by use of specially designed software (Perisoft; Perimed A.B.).

We measured body fat using the deuterium dilution method, because of its acceptability in all age groups. ${ }^{20}$ Because the percentage of fat-free mass (FFM) that consists of water is known (this "hydration constant" is, for example, $73 \%$ in adults, but greater in children ${ }^{21}$ ), FFM can be estimated if the total amount of water in the body (TBW) is known. We used an adapted version of the Maastricht protocol. ${ }^{22}$ The children ingested $25 \mathrm{~mL}$ of a $5 \%$ deuterium oxide solution under supervision of the researchers, after a baseline urine sample was collected at home first. Absorbent cotton wool rolls were placed in the children's diapers by their parents to collect the urine samples. At least 6 hours after ingestion of the deuterium, to allow for full equilibration with the body water, a second urine sample was collected at home by the parents, and the exact time between ingestion of the deuterium oxide and collection of the sample was recorded. The parents sent these samples back to the hospital in glass containers (to prevent evaporation) by mail and the samples were stored at $-20^{\circ} \mathrm{C}$ until analysis.
The samples (baseline and enriched) were analyzed via isotope ratio mass spectrometry (Optima; Micromass, Manchester, United Kingdom). TBW was calculated as deuterium dilution space divided by 1.04 to adjust for the $4 \%$ exchange of the deuterium oxide with the nonwater compartment in the body.

Subsequently, FFM was calculated as follows:

$$
\mathrm{FFM}_{\text {boys }}(\mathrm{kg})=\frac{T B W}{0.77} \text { and } \mathrm{FFM}_{\text {girls }}(\mathrm{kg})=\frac{T B W}{0.78}
$$

The percentage of body fat was calculated by the following formula:

$$
\% \text { fat }=\frac{\text { weight }-F F M}{\text { weight }} * 100
$$

Birth weight was measured on an electronic scale (accurate to $1 \mathrm{~g}$ ) as part of the usual delivery protocol in our hospital. Supine length was measured using a measuring table $(0,6$, and 12 months) or, if possible, standing (24 months). The measurements were accurate to $1 \mathrm{~mm}$. Head circumference was measured via a nonstretchable tape, accurate to $1 \mathrm{~mm}$, around the most protruding points of occiput and forehead. SD scores (z-scores) were calculated accurate to 1 day, as described earlier (data at 12 and 24 months were standardized similar to data at 6 months). ${ }^{10}$ We furthermore collected weight, length, and head circumference data from the infant and child welfare centers and extracted the measurements closest to 30 days ( 1 month) and 90 days ( 3 months).

Detailed collection and scaling methods of covariates have been described previously. ${ }^{17}$ We collected the following variables from hospital records: sex, ${ }^{23,24}$ gestational age (based on the first day of the last menstrual period, recorded accurate to one day), ${ }^{25}$ maternal hypertension during pregnancy (includes preexistent hypertension, gestational hypertension, preeclampsia and HELLP syndrome [ie, Hemolysis, Elevated Liver enzymes, Low Platelet count]), ${ }^{24}$ gestational diabetes, ${ }^{26}$ and mode of delivery. ${ }^{27}$ Furthermore, whether the child was born after an assisted pregnancy (including hormonal stimulation of ovulation, in vitro fertilization, and intracytoplasmic sperm injection) was recorded, as was parity and blood pressure of the infant/child. Blood pressure was measured by use of an arm circumference-adjusted cuff and an automated blood pressure recorder (at 0 months: Philips M1008B module, Eindhoven, The Netherlands; at 6, 12, and 24 months: Dinamap Pro 300, GE Healthcare, Chalfont St. Giles, United Kingdom) when the infant was quiet or asleep.

We interviewed the parents and collected data on maternal smoking during pregnancy, ${ }^{28}$ breast feeding, ${ }^{29}$ parental ethnic background (Dutch descent or not), level of education, and family history of cardiovascular disease. Level of education was expressed dichotomously: $0=$ from no education to lower secondary education, 1 = from intermediate level secondary school to tertiary education. Family history of cardiovascular disease had 4 categories: $0=$ no known cardiovascular diseases in the family; $1=$ hypertension, 
hypercholesterolemia, or type 2 diabetes in a second-degree relative $<60$ years; $2=$ cardiovascular event (transient ischemic attack, stroke, or myocardial infarction) in a second-degree relative $<60$ years; and $3=$ hypertension, hypercholesterolemia, type 2 diabetes, or a cardiovascular event in a first-degree relative. Only 1 infant had a cardiovascular event in a first-degree relative. We always included the time point $(0,6,12$, or 24$)$ as a covariate in our analyses.

\section{Statistical Analyses}

Interobserver variability for baseline and maximum perfusion in a random subsample of 20 newborns was assessed previously and reached an intra-class coefficient of $>0.98 .{ }^{17}$ To compare group means between the children with and without a (successful) visit at the age of 24 months, the independent $t$ test was used for continuous variables, the $\chi^{2}$ test was used for dichotomous variables, and the MannWhitney $U$ test was used to compare the family history of cardiovascular disease. If a variable predicted completion of the final visit, it was included in the subsequent (multilevel) models.

We applied multilevel linear regression to take our 4 subsequent measurements into account. Because multilevel analysis requires complete data for all covariates, we imputed missing values in the covariates by use of multiple imputation and used this data file for the multilevel analyses only. We assumed a missing at random pattern for our missing data, which means that our missing observations would only be related to variables we measured. First, we performed an initial analysis for both response to acetylcholine and nitroprusside including all covariates and all growth intervals simultaneously for the 4 different growth variables (weight, length, weight-for-length, and head circumference). Second, we constructed a final model in which we excluded all variables from the initial model with $P>.10$ (in the pooled results of the 5 imputed data sets). As exceptions, we always kept time point, sex, and baseline perfusion in the models. For response to acetylcholine, we kept hypertension during pregnancy in the model because we identified its effect earlier. ${ }^{17}$ For response to nitroprusside, we always kept family history of cardiovascular disease and gestational age in the model because they proved significant in our previous final models. ${ }^{10}$ We report the data obtained by the imputed data file.

Bivariate Pearson correlation coefficients were calculated between fat percentage, the other anthropometric variables, and maximum perfusion values at the age of 2 years. Associations between fat percentage at the age of 2 years and growth were tested by linear regression. Analogously to our multilevel approach, first a multivariable model was constructed containing all available covariates, except the perfusion variables. Second, only the covariates with $P<.10$ were kept in the model. Because we aimed to test all growth windows simultaneously, only children with complete data could be included in these models. All analyses were performed using SPSS Statistics version 20 (IBM, Armonk, New York).

\section{Results}

The Figure (available at www.jpeds.com) shows the number of measurements at each time point. The total lossto-follow-up at 24 months was 16 children (15\%), with an additional 2 unsuccessful measurements at 24 months. The characteristics of the children with a (successful) visit at the age of 24 months are given in Table I. There were no differences between children with and without a measurement for the variables shown in Table I, except for a greater prevalence of low educated mothers in the children without a visit compared with the children with a visit, $67 \%$ vs $36 \%, P=.02$. Two children had negative calculated fat percentages, which indicated the occurrence of technical errors (for example unrecorded spilling). These were excluded from the analysis.

Weight gain from 0-1 month was associated inversely with maximum perfusion in response to acetylcholine $(b=-8.28$

\begin{tabular}{|c|c|c|c|}
\hline Variables & Mean/n & SD/\% & n (\%) missing \\
\hline \multicolumn{4}{|l|}{ Birth } \\
\hline $\begin{array}{l}\text { Age at day of measurement, } d \text {, } \\
\text { mean, SD }\end{array}$ & 2.1 & 1.4 & \\
\hline Weight, Z-score, mean, SD & -0.4 & 1.3 & \\
\hline $\begin{array}{l}\text { Born small for gestational age } \\
\quad(<\mathrm{p} 10), \mathrm{n}, \%\end{array}$ & 21 & 24.4 & \\
\hline \multicolumn{4}{|l|}{24 months } \\
\hline Age at follow-up visit, $d$, mean, SD & 738 & 15 & \\
\hline Weight, Z-score, mean, SD & -0.3 & 1.0 & \\
\hline \multicolumn{4}{|l|}{ Growth } \\
\hline Weight, $\Delta$ Z-score $0-1$, mean, SD & -0.3 & 0.8 & $3(3.5)$ \\
\hline Weight, $\Delta$ Z-score 1 -3, mean, SD & 0.5 & 0.7 & $3(3.5)$ \\
\hline Weight, $\Delta$ Z-score 3-6, mean, SD & 0.0 & 0.6 & $5(5.8)$ \\
\hline Weight, $\Delta$ Z-score $0-6$, mean, SD & 0.2 & 1.2 & $5(5.8)$ \\
\hline Weight, $\Delta$ Z-score 6-12, mean, SD & -0.1 & 0.5 & $6(7.0)$ \\
\hline Weight, $\Delta$ Z-score $12-24$, mean, SD & 0.0 & 0.4 & $2(2.3)$ \\
\hline \multicolumn{4}{|l|}{ Pregnancy } \\
\hline Gestational age, wk, mean, SD & 39.3 & 1.4 & \\
\hline Hypertension during pregnancy, n, \% & 16 & 18.6 & \\
\hline Gestational diabetes, $n, \%$ & 3 & 3.5 & \\
\hline Smoking during pregnancy, $\mathrm{n}, \%$ & 13 & 15.1 & \\
\hline Assisted pregnancy, n, \% & 15 & 17.4 & \\
\hline Cesarean delivery, $\mathrm{n}, \%$ & 59 & 68.6 & \\
\hline Multipara, n, \% & 33 & 38.4 & \\
\hline \multicolumn{4}{|l|}{ General } \\
\hline Male, $n, \%$ & 36 & 41.9 & \\
\hline $\begin{array}{l}\text { Systolic blood pressure at } 24 \text { months, } \\
\mathrm{mm} \mathrm{Hg} \text {, mean, SD }\end{array}$ & 93.1 & 8.3 & $13(15.1)$ \\
\hline Non-Dutch ethnic background, n, \% & 13 & 15.1 & \\
\hline Breast feeding, $n, \%$ & 61 & 70.9 & \\
\hline Low education level, father, n, \% & 27 & 31.4 & \\
\hline Low education level, mother, $n, \%$ & 31 & 36.0 & \\
\hline \multicolumn{4}{|l|}{$\begin{array}{l}\text { Family history of cardiovascular } \\
\text { disease, } \mathrm{n}, \%\end{array}$} \\
\hline No known cardiovascular disease & 24 & 27.9 & \\
\hline $\begin{array}{l}\text { Risk factors in second-degree } \\
\text { relative }\end{array}$ & 27 & 31.4 & \\
\hline Event in second-degree relative & 23 & 26.7 & \\
\hline $\begin{array}{l}\text { Risk factors or event in } \\
\text { first-degree relative }\end{array}$ & 12 & 14.0 & \\
\hline Height father, $\mathrm{m}$, mean, SD & 1.81 & 0.08 & $1(1.2)$ \\
\hline Weight father, $\mathrm{kg}$, mean, SD & 81.1 & 12.9 & $2(2.3)$ \\
\hline Height mother, $m$, mean, SD & 1.69 & 0.06 & \\
\hline Weight mother, $\mathrm{kg}$, mean, SD & 67.5 & 14.1 & \\
\hline
\end{tabular}


PU per $\Delta$ z-score, $P=.03$; Table II). Weight gain from $0-1$ month was related positively to maximum perfusion in response to nitroprusside $(\mathrm{b}=10.12 \mathrm{PU}$ per $\Delta \mathrm{z}$-score, $P=.04)$, as was birth weight $(\mathrm{b}=8.02 \mathrm{PU}$ per $\mathrm{z}$-score, $P=.02)$. Length, weight-for-length, and head circumference birth or growth variables were not associated with maximum perfusion. Fat percentage did not have a significant effect in any of the models, for example in the weight model: $\mathrm{b}=0.06, P=.94$.

Fat percentage was correlated in bivariable analysis to weight-for-length $\mathrm{z}$-score at 2 years $(\mathrm{r}=0.30, P=.01)$, but not to weight, length, or head circumference z-scores and not to maximum perfusion in response to acetylcholine $(\mathrm{r}=0.09, P=.48)$ or nitroprusside $(\mathrm{r}=-0.08, P=.50)$ (data not shown).

Faster weight gain between 6 and 12 months was associated with a greater percent body fat at the age of 2 years $(b=3.28 \%$ per $\Delta z$-score, $P=.02$; Table III). This was also the case for a faster increase in weight-for-length in nearly all growth periods, most strikingly between 6 and 12 months ( $\mathrm{b}=3.68 \%$ per $\Delta \mathrm{z}$-score, $P<.0001)$. Finally, head growth from 3 to 6 months was positively associated with percent body fat at the age of 2 years $(b=4.57 \%$ per $\Delta z$-score, $P=.003)$.

\section{Discussion}

In contrast to what we hypothesized and to previous studies in older children, we did not find a correlation between percent body fat and vascular function at the age of 2 years. ${ }^{13-16}$ In our growth models percent body fat did not have any effect. We hypothesize our study population might have been too young: in the referenced literature, the children were all $>9$ years of age. The degree of fat accumulation during childhood-after fast infant weight gain-that is associated with complications such as increased blood pressure and impaired insulin sensitivity may not have been attained yet at the age of 2 years. ${ }^{30}$ Alternatively, an observed harmful effect of percent body fat may be a proxy for accelerated infant growth, because growth was not measured in these studies. We recommend future studies to take both infant and childhood growth data into account, as well as obesity and percent

Table II. Associations between anthropometry at birth, growth, and maximum perfusion in response to acetylcholine and nitroprusside

\begin{tabular}{|c|c|c|c|c|c|c|c|c|}
\hline \multirow[b]{3}{*}{ Variables } & \multicolumn{4}{|c|}{ Acetylcholine $(n=104)$} & \multicolumn{4}{|c|}{ Nitroprusside $(n=102)$} \\
\hline & \multicolumn{2}{|c|}{ All covariates } & \multicolumn{2}{|c|}{ Final model } & \multicolumn{2}{|c|}{ All covariates } & \multicolumn{2}{|c|}{ Final model } \\
\hline & b & $\boldsymbol{P}$ & b & $\boldsymbol{P}$ & b & $P$ & b & $\boldsymbol{P}$ \\
\hline \multicolumn{9}{|l|}{ Weight } \\
\hline Birth weight Z-score & -1.20 & .74 & 0.68 & .79 & 6.70 & .13 & 8.02 & $.02^{\star}$ \\
\hline Growth 0-1 mo ( $\Delta$ Z-score) & -8.85 & .15 & -8.28 & $.03^{*}$ & 14.96 & $.02^{\star}$ & 10.12 & $.04^{*}$ \\
\hline Growth 1-3 mo ( $\Delta$ Z-score) & -8.25 & .13 & -4.85 & .25 & -5.26 & .46 & -2.09 & .73 \\
\hline Growth 3-6 mo ( $\Delta$ Z-score) & -2.87 & .63 & 0.82 & .87 & 3.88 & .56 & 2.92 & .60 \\
\hline Growth 6-12 mo ( $\Delta$ Z-score) & 0.96 & .87 & 3.44 & .50 & -0.23 & .98 & -0.38 & .96 \\
\hline Growth 12-24 mo ( $\Delta$ Z-score) & 1.85 & .76 & 2.02 & .72 & -4.18 & .55 & -1.72 & .78 \\
\hline \multicolumn{9}{|l|}{ Length } \\
\hline Birth length Z-score & 4.21 & .24 & 4.76 & .07 & 4.53 & .28 & 6.22 & .054 \\
\hline Growth 0-1 mo ( $\Delta$ Z-score) & -4.26 & .30 & -3.53 & .25 & -0.14 & .98 & 1.51 & .81 \\
\hline Growth 1-3 mo ( $\Delta$ Z-score) & -9.62 & .08 & -4.74 & .29 & -3.03 & .75 & -2.98 & .71 \\
\hline Growth 3-6 mo ( $\Delta$ Z-score) & -1.69 & .71 & 1.17 & .77 & -2.80 & .61 & -2.68 & .59 \\
\hline Growth 6-12 mo ( $\Delta$ Z-score) & -1.79 & 68 & 0 & 1.00 & -3.98 & .46 & -3.20 & .46 \\
\hline Growth 12-24 mo ( $\Delta$ Z-score) & -1.47 & .78 & -0.08 & .99 & -2.87 & .65 & -3.25 & .57 \\
\hline \multicolumn{9}{|l|}{ Weight-for-length } \\
\hline Birth weight-for-length Z-score & -1.56 & .72 & -2.38 & .54 & 5.13 & .23 & 7.09 & .06 \\
\hline Growth 0-1 mo ( $\Delta$ Z-score) & -2.73 & .58 & -3.31 & .43 & 5.36 & .20 & 4.95 & .18 \\
\hline Growth 1-3 mo ( $\Delta$ Z-score) & -3.85 & .49 & -3.85 & .44 & 2.70 & .67 & 3.94 & .45 \\
\hline Growth 3-6 mo ( $\Delta$ Z-score) & -3.89 & .41 & -2.43 & .55 & 3.88 & .46 & 5.79 & .19 \\
\hline Growth 6-12 mo ( $\Delta$ Z-score) & 5.59 & .34 & 6.73 & .17 & 6.55 & .26 & 6.70 & .18 \\
\hline Growth 12-24 mo ( $\Delta$ Z-score) & 6.25 & .31 & 6.91 & .21 & -0.83 & .89 & 0.49 & .92 \\
\hline \multicolumn{9}{|l|}{ Head circumference } \\
\hline Birth head circumference Z-score & 3.03 & .40 & 3.64 & .16 & 4.24 & .34 & 4.53 & .21 \\
\hline Growth 0-1 mo ( $\Delta$ Z-score) & -2.44 & .69 & -2.01 & .62 & 2.41 & .70 & 2.18 & .67 \\
\hline Growth 1-3 mo ( $\Delta$ Z-score) & -0.61 & .94 & -0.56 & .94 & 3.49 & .62 & 1.90 & .78 \\
\hline Growth 3-6 mo ( $\Delta$ Z-score) & -5.11 & .41 & -3.57 & .47 & -4.89 & .49 & -4.85 & .43 \\
\hline Growth 6-12 mo ( $\Delta$ Z-score) & -7.56 & .37 & -3.46 & .52 & -6.54 & .46 & -4.09 & .61 \\
\hline Growth 12-24 mo ( $\Delta$ Z-score) & -5.52 & .48 & -2.70 & .71 & -3.88 & .66 & -3.23 & .65 \\
\hline
\end{tabular}

The outcome variable is maximum perfusion (in PU) in response to acetylcholine or nitroprusside.

The data were analyzed by multilevel linear regression with compound symmetric covariance, all 6 parameters were tested simultaneously in 1 model.

"All covariates" constitutes time point, baseline perfusion, fat percentage, sex, gestational age, parental weight, parental height, parental socioeconomic status, race, familial history of cardiovascular disease, assisted pregnancy, parity, hypertension during pregnancy, gestational diabetes, maternal smoking, delivery mode, breast feeding, and systolic blood pressure of the child.

The final acetylcholine models were adjusted for time point, sex, baseline perfusion, hypertension during pregnancy, maternal socioeconomic status, and gestational diabetes. The final model for weight was additionally adjusted for paternal socioeconomic status.

The final nitroprusside models were adjusted for time point, sex, baseline perfusion, maternal socioeconomic status, gestational age, familial history of cardiovascular disease, and race. The final models for weight and length were additionally adjusted for maternal smoking.

*Indicates a significant association $(P<.05)$. 
Table III. Association between anthropometry at birth, growth, and fat percentage at the age of 2 years

\begin{tabular}{|c|c|c|c|c|}
\hline \multirow[b]{2}{*}{ Variables } & \multicolumn{2}{|c|}{ All covariates } & \multicolumn{2}{|c|}{ Final model } \\
\hline & b & $\boldsymbol{P}$ & b & $\boldsymbol{P}$ \\
\hline \multicolumn{5}{|l|}{ Weight $(n=56, n=66)$} \\
\hline Birth weight Z-score & 0.69 & .52 & 0.42 & .50 \\
\hline Growth 0-1 mo ( $\Delta$ Z-score) & 0.80 & .68 & 1.13 & .20 \\
\hline Growth 1-3 mo ( $\Delta$ Z-score) & 2.36 & .14 & 0.38 & .72 \\
\hline Growth 3-6 mo ( $\Delta$ Z-score) & 0.004 & 1.00 & 0.35 & .81 \\
\hline Growth 6-12 mo ( $\Delta$ Z-score) & 4.80 & $.04^{*}$ & 3.28 & $.02^{*}$ \\
\hline Growth 12-24 mo ( $\Delta$ Z-score) & 1.01 & .57 & 1.33 & .36 \\
\hline \multicolumn{5}{|l|}{ Length $(n=48, n=56)$} \\
\hline Birth length Z-score & 1.24 & .32 & 1.05 & .18 \\
\hline Growth 0-1 mo ( $\Delta$ Z-score) & 0.31 & .84 & 0.08 & .92 \\
\hline Growth 1-3 mo ( $\Delta$ Z-score) & 1.38 & .36 & 0.94 & .35 \\
\hline Growth 3-6 mo ( $\Delta$ Z-score) & 1.97 & .25 & 1.39 & .23 \\
\hline Growth 6-12 mo ( $\Delta$ Z-score) & 0.64 & .70 & 0.61 & .55 \\
\hline Growth 12-24 mo ( $\Delta$ Z-score) & 1.04 & .58 & -0.36 & .78 \\
\hline \multicolumn{5}{|l|}{ Weight-for-length $(n=48, n=56)$} \\
\hline Birth weight-for-length Z-score & 1.45 & .14 & 1.08 & .13 \\
\hline Growth 0-1 mo ( $\Delta$ Z-score) & 2.53 & $.04^{*}$ & 1.87 & $.02^{*}$ \\
\hline Growth 1-3 mo ( $\Delta$ Z-score) & 2.24 & .09 & 2.00 & $.02^{*}$ \\
\hline Growth 3-6 mo ( $\Delta$ Z-score) & 1.43 & .21 & 1.44 & .08 \\
\hline Growth 6-12 mo ( $\Delta$ Z-score) & 4.66 & $.004^{*}$ & 3.68 & $<.0001^{*}$ \\
\hline Growth $12-24$ mo ( $\Delta$ Z-score) & 1.28 & .28 & 1.95 & $.03^{*}$ \\
\hline \multicolumn{5}{|l|}{ Head circumference $(n=44, n=49)$} \\
\hline Birth head circumference Z-score & 1.05 & .34 & 0.54 & .39 \\
\hline Growth 0-1 mo ( $\Delta$ Z-score) & 2.26 & .22 & 1.25 & .12 \\
\hline Growth 1-3 mo ( $\Delta$ Z-score) & -0.88 & .66 & -1.52 & .28 \\
\hline Growth 3-6 mo ( $\Delta$ Z-score) & 2.81 & .18 & 4.57 & $.003^{*}$ \\
\hline Growth 6-12 mo ( $\Delta$ Z-score) & 1.85 & .50 & 1.71 & .28 \\
\hline Growth 12-24 mo ( $\Delta$ Z-score) & 0.45 & .87 & 0.19 & .91 \\
\hline
\end{tabular}

The outcome variable is fat percentage, as determined by the deuterium dilution method. The data were analyzed by linear regression, all 6 parameters were tested simultaneously in 1 model.

The 2 n's refer to the number of children included in the models using all covariates and the final model, respectively.

"All covariates" constitutes sex, gestational age, parental weight, parental height, parental socioeconomic status, race, familial history of cardiovascular disease, assisted pregnancy, parity hypertension during pregnancy, gestational diabetes, maternal smoking, delivery mode, breast feeding, and systolic blood pressure of the child.

The covariates in the final models were: race (for weight); sex, maternal height and hypertension during pregnancy (for length); sex, maternal height and weight, hypertension during pregnancy and race (for weight-for-length); and sex, paternal height and parity (for head circumference).

*Indicates a significant association $(P<.05)$.

body fat when assessing the association between growth and vascular function.

Earlier we found that infant growth, particularly during the first 3 months, is related inversely to endothelial function at the age of 6 months. ${ }^{10}$ It is important to observe that this association is still relevant later in life, when growth rates are slower. We can now confirm that this association persists at least up till the age of 2 years, 1 year after the fast growth period of 0-1 year of age ended. We suggest there may be a harmful effect of accelerated weight gain during the first month on the development of the endothelium, which might eventually contribute to the increased risk fast growing infants have for metabolic syndrome later in life. ${ }^{3,5}$ Our results are consistent with a recent study, which also linked accelerated weight gain in small for gestational age individuals (measured as change from birth to adulthood) to later, adult, endothelial function. ${ }^{31}$

As we suggested previously, we think that accelerated growth results in a second, stronger, hit to the already-existing increased risk for endothelial dysfunction and cardiovascular disease in small for gestational age individuals. ${ }^{2,10,17}$ In the present study, the models containing both birth weight and postnatal growth did not show an association between birth weight and endothelial function, and growth did show an inverse association. Small-for-gestational age infants are more likely to show accelerated growth, so future studies should test the effects of birth weight and growth simultaneously. ${ }^{32}$ It should be noted that the fact that birth weight as a crude measure was statistically not important when growth was considered, does not mean that intrauterine growth patterns could still be important. Mechanistically speaking, there are data describing modifying effects of (accelerated) growth on the hypothalamus-pituitaryadrenal axis, growth hormone, leptin, adipocytes and epigenetic profiles. ${ }^{33-35}$

Contrary to our expectations, we identified positive associations between birth weight and response to nitroprusside (endothelium-independent vasodilation) and between weight growth from 0-1 month and response to nitroprusside. In the literature, however, acetylcholine and nitroprusside responses mostly are affected in the same direction, or nitroprusside responses remain unaffected. For example, both are negatively related to percent body fat in children. ${ }^{16}$ Should our results be confirmed in other studies, one may speculate that the smooth muscle cells increase their sensitivity to $\mathrm{NO}$ when the infant grows fast, to compensate for suboptimal endothelial release of NO, prostanoids and other vasodilatory mediators. This may also imply that the endothelial responses to acetylcholine are even more impaired after accelerated growth than we have measured, because these children are more likely to have more responsive smooth muscle cells.

Data from a healthy term study population can potentially be extrapolated to the general population. Furthermore, we tested many confounders, birth weight and 5 growth windows simultaneously, which helps to adjust for the effects on each other and avoids multiple testing issues. As a limitation, although the deuterium dilution method is considered a valid measure for body composition, we relied on the expertise of the parents at home for sample collection, which may have affected the reliability of our measurements. Second, the moderate study size may have resulted in false-negative observations. As in all observational studies, no conclusions can be drawn with regard to causality. Our study is limited to the first 2 years of life. Later growth windows have also been linked to later cardiovascular disease and were not studied here. ${ }^{36}$

We found evidence for an inverse association between growth from 0-1 month and endothelial function at the age of 2 years. The expanding body of evidence on the potential harmful effects of accelerated growth on later (cardiovascular) disease may lead to clinical guidelines on prevention of accelerated growth in early infancy. First, interventional studies will be needed to establish a causal relationship. Further research is needed into optimal early infant growth 
to yield adequate primary prevention of cardiovascular outcomes without compromising neurologic development.

The authors would like to thank Marian Quanjel, MD, Marieke Veelers, Cecile Wolfs, Irene Scheerder, MD, Rick Gerzon, MD, Gwen van Heesch, MD, Gertrude van den Brink, MD, Stéphanie Balink, MD, and Oenone Mikes, MD (Maastricht University Medical Centre) for their contributions to the data collection.

Submitted for publication Jun 7, 2014; last revision received Oct 14, 2014; accepted Nov 25, 2014.

Reprint requests: Robbert N. H. Touwslager, MD, PhD, Department of Pediatrics, Maastricht University Medical Centre, P.O. Box 5800, 6202 AZ Maastricht, The Netherlands. E-mail: bob.touwslager@mumc.nl

\section{References}

1. Yusuf S, Reddy S, Ounpuu S, Anand S. Global burden of cardiovascular diseases: part I: general considerations, the epidemiologic transition, risk factors, and impact of urbanization. Circulation 2001;104:2746-53.

2. Barker DJ, Osmond C, Golding J, Kuh D, Wadsworth ME. Growth in utero, blood pressure in childhood and adult life, and mortality from cardiovascular disease. BMJ 1989;298:564-7.

3. Kerkhof GF, Leunissen RW, Hokken-Koelega AC. Early origins of the metabolic syndrome: role of small size at birth, early postnatal weight gain, and adult IGF-I. J Clin Endocrinol Metab 2012;97:2637-43.

4. Singhal A, Cole TJ, Fewtrell M, Deanfield J, Lucas A. Is slower early growth beneficial for long-term cardiovascular health? Circulation 2004;109:1108-13.

5. Khuc K, Blanco E, Burrows R, Reyes M, Castillo M, Lozoff B, et al. Adolescent metabolic syndrome risk is increased with higher infancy weight gain and decreased with longer breast feeding. Int J Pediatr 2012;2012:478610.

6. Ekelund U, Ong KK, Linne Y, Neovius M, Brage S, Dunger DB, et al. Association of weight gain in infancy and early childhood with metabolic risk in young adults. J Clin Endocrinol Metab 2007;92:98-103.

7. Koletzko B, von Kries R, Closa R, Escribano J, Scaglioni S, Giovannini M, et al. Lower protein in infant formula is associated with lower weight up to age $2 \mathrm{y}$ : a randomized clinical trial. Am J Clin Nutr 2009;89:1836-45.

8. Ong KK. Catch-up growth in small for gestational age babies: good or bad? Curr Opin Endocrinol Diabetes Obes 2007;14:30-4.

9. Lazdam M, Lewandowski AJ, Kylintireas I, Cunnington C, Diesch J, Francis $\mathrm{J}$, et al. Impaired endothelial responses in apparently healthy young people associated with subclinical variation in blood pressure and cardiovascular phenotype. Am J Hypertens 2012;25:46-53.

10. Touwslager RN, Gerver WJ, Tan FE, Gielen M, Zeegers MP, Zimmermann LJ, et al. Influence of growth during infancy on endothelium-dependent vasodilatation at the age of 6 months. Hypertension 2012;60:1294-300.

11. Druet C, Stettler N, Sharp S, Simmons RK, Cooper C, Smith GD, et al. Prediction of childhood obesity by infancy weight gain: an individuallevel meta-analysis. Paediatr Perinat Epidemiol 2012;26:19-26.

12. Victora CG, Sibbritt D, Horta BL, Lima RC, Cole T, Wells J. Weight gain in childhood and body composition at 18 years of age in Brazilian males. Acta Paediatr 2007;96:296-300.

13. Meyer AA, Kundt G, Steiner M, Schuff-Werner P, Kienast W. Impaired flow-mediated vasodilation, carotid artery intima-media thickening, and elevated endothelial plasma markers in obese children: the impact of cardiovascular risk factors. Pediatrics 2006;117:1560-7.

14. Woo KS, Chook P, Yu CW, Sung RY, Qiao M, Leung SS, et al. Overweight in children is associated with arterial endothelial dysfunction and intimamedia thickening. Int J Obes Relat Metab Disord 2004;28:852-7.
15. Zhu W, Huang X, He J, Li M, Neubauer H. Arterial intima-media thickening and endothelial dysfunction in obese Chinese children. Eur J Pediatr 2005;164:337-44.

16. Khan F, Green FC, Forsyth JS, Greene SA, Morris AD, Belch JJ. Impaired microvascular function in normal children: effects of adiposity and poor glucose handling. J Physiol 2003;551:705-11.

17. Touwslager RN, Houben AJ, Gielen M, Zeegers MP, Stehouwer CD, Zimmermann LJ, et al. Endothelial vasodilatation in newborns is related to body size and maternal hypertension. J Hypertens 2012;30:124-31.

18. Turner J, Belch JJ, Khan F. Current concepts in assessment of microvascular endothelial function using laser Doppler imaging and iontophoresis. Trends Cardiovasc Med 2008;18:109-16.

19. Feelisch M. The use of nitric oxide donors in pharmacological studies. Naunyn Schmiedebergs Arch Pharmacol 1998;358:113-22.

20. Wells JC, Fewtrell MS. Measuring body composition. Arch Dis Child 2006;91:612-7.

21. Butte NF, Hopkinson JM, Wong WW, Smith EO, Ellis KJ. Body composition during the first 2 years of life: an updated reference. Pediatr Res 2000;47:578-85.

22. Westerterp KR, Wouters L, van Marken Lichtenbelt WD. The Maastricht protocol for the measurement of body composition and energy expenditure with labeled water. Obes Res 1995;3(Suppl 1):49-57.

23. Stark MJ, Clifton VL, Wright IM. Sex-specific differences in peripheral microvascular blood flow in preterm infants. Pediatr Res 2008;63:415-9.

24. Stark MJ, Clifton VL, Wright IM. Neonates born to mothers with preeclampsia exhibit sex-specific alterations in microvascular function. Pediatr Res 2009;65:292-5.

25. Norman M, Martin H. Preterm birth attenuates association between low birth weight and endothelial dysfunction. Circulation 2003;108:9961001.

26. Segar EM, Norris AW, Yao JR, Hu S, Koppenhafer SL, Roghair RD, et al. Programming of growth, insulin resistance and vascular dysfunction in offspring of late gestation diabetic rats. Clin Sci (Lond) 2009;117:129-38.

27. Martin H, Norman M. Skin microcirculation before and after local warming in infants delivered vaginally or by caesarean section. Acta Paediatr 1997;86:261-7.

28. Hutchison SJ, Glantz SA, Zhu BQ, Sun YP, Chou TM, Chatterjee K, et al. In-utero and neonatal exposure to secondhand smoke causes vascular dysfunction in newborn rats. J Am Coll Cardiol 1998;32:1463-7.

29. Khan F, Green FC, Forsyth JS, Greene SA, Newton DJ, Belch JJ. The beneficial effects of breastfeeding on microvascular function in 11- to 14-year-old children. Vasc Med 2009;14:137-42.

30. Kerkhof GF, Hokken-Koelega AC. Rate of neonatal weight gain and effects on adult metabolic health. Nat Rev Endocrinol 2012;8:689-92.

31. Leunissen RW, Kerkhof GF, Stijnen T, Hokken-Koelega AC. Effect of birth size and catch-up growth on adult blood pressure and carotid intima-media thickness. Horm Res Paediatr 2012;77:394-401.

32. Hokken-Koelega AC, De Ridder MA, Lemmen RJ, Den Hartog H, De Muinck Keizer-Schrama SM, Drop SL. Children born small for gestational age: do they catch up? Pediatr Res 1995;38:267-71.

33. Guilloteau P, Zabielski R, Hammon HM, Metges CC. Adverse effects of nutritional programming during prenatal and early postnatal life, some aspects of regulation and potential prevention and treatments. J Physiol Pharmacol 2009;60(Suppl 3):17-35.

34. Isganaitis E, Jimenez-Chillaron J, Woo M, Chow A, DeCoste J, Vokes M, et al. Accelerated postnatal growth increases lipogenic gene expression and adipocyte size in low-birth weight mice. Diabetes 2009;58:1192-200.

35. Waterland RA, Lin JR, Smith CA, Jirtle RL. Post-weaning diet affects genomic imprinting at the insulin-like growth factor 2 (Igf2) locus. Hum Mol Genet 2006;15:705-16.

36. Eriksson JG. Early growth, and coronary heart disease and type 2 diabetes: experiences from the Helsinki Birth Cohort Studies. Int J Obes 2006;30(Suppl 4):S18-22. 


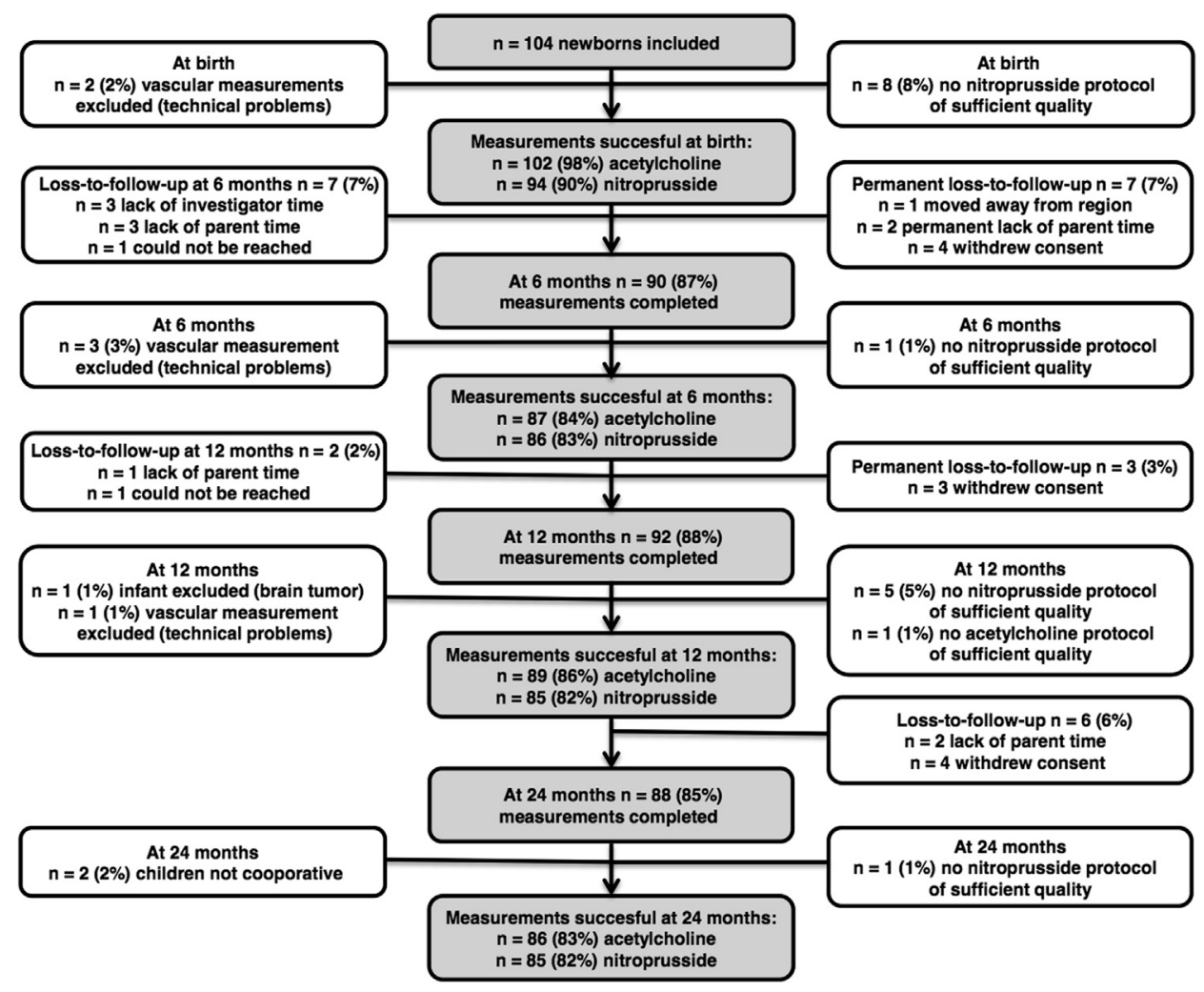

Figure. Participant flow. 